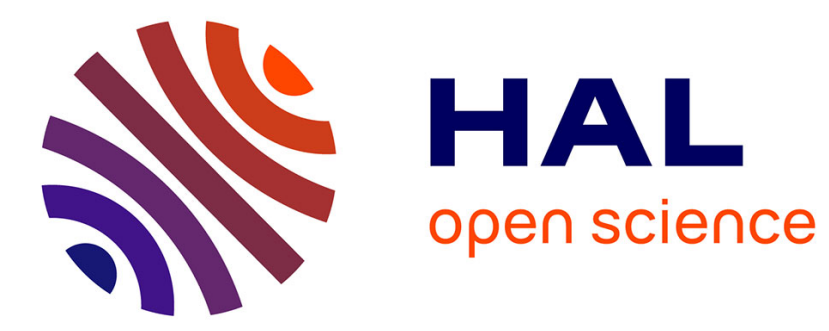

\title{
Recent transformations in the French urban system
}

Denise Pumain, Thérèse Saint-Julien

\section{To cite this version:}

Denise Pumain, Thérèse Saint-Julien. Recent transformations in the French urban system. Espace

Géographique, 1993, 1 (1), pp.157 - 165. 10.3406/spgeo.1993.3199 . hal-01760565

\section{HAL Id: hal-01760565 \\ https://hal.science/hal-01760565}

Submitted on 6 Apr 2018

HAL is a multi-disciplinary open access archive for the deposit and dissemination of scientific research documents, whether they are published or not. The documents may come from teaching and research institutions in France or abroad, or from public or private research centers.
L'archive ouverte pluridisciplinaire HAL, est destinée au dépôt et à la diffusion de documents scientifiques de niveau recherche, publiés ou non, émanant des établissements d'enseignement et de recherche français ou étrangers, des laboratoires publics ou privés. 


\title{
Recent transformations in the French urban system
}

\section{Mme Denise Pumain, Thérèse Saint-Julien}

\begin{abstract}
Evolution in the socio-economic characteristics of the 138 largest urban areas in Fiance between 1954 and 1975 consists of three trends, interpreted in this article according to their incidence on the structure of the urban system. The most important includes the changes which have equally affected all built up areas, and provoked a translation of the system without changing its form. The other two trends regroup differential changes: one has increased the likeness of the urban areas' profiles by reducing the functional specialisations based on the geographical concentration of sectors of activity; the other has introduced a new segregation in socio-economic urban structures, between "growth centres" and "peripheral" nuclei
\end{abstract}

\section{Citer ce document / Cite this document :}

Pumain Denise, Saint-Julien Thérèse. Recent transformations in the French urban system. In: Espace géographique. Espaces, modes d'emploi. Two decades of l'Espace géographique, an anthology. Special issue in English. 1993. pp. 157-165;

doi : $10.3406 /$ spgeo.1993.3199

http://www.persee.fr/doc/spgeo_0046-2497_1993_hos_1_1_3199

Document généré le 06/09/2016 


\title{
Recent transformations in the French urban system
}

\author{
Denise Pumain, Thérèse Saint-Julien
}

University of Paris I

ABSTRACT. - Evolution in the socio-economic characteristics of the 138 largest urtan areas in France between 1954 and 1975 consists of three trends, interpreted in this article according to their incidence on the structure of the urban system. The most important includes the changes which have equally affected all built up areas, and provoked a translation of the system without changing its form. The other two trends regroup differential changes: one has increased the likeness of the urban areas' profiles by reducing the functional specialisations based on the geographical concentration of sectors of activity; the other has introduced a new segregation in socio-economic urban structures, between "growth centres" and "peripheral" nuclei.

FRANCE (1954-1975), MULTTVARUATE ANALYSS, URBAN SYSTEM
This paper is a follow-up on research about the recent evolution (1954-1975) of major urban areas in France (Pumain \& Saint-Julien, 1978). Here we attempt to interpret the changes that have affected the socio-economic characteristics of this urban system by considering urban areas as interdependent components of a single system (Berry, 1964).

Because of our sources, our survey only deals with the totality of provincial urban areas with more than 20,000 inhabitants as of 1954. Our "urban system" thus includes neither Paris nor small towns. This approach is interesting on three accounts. On the one hand, it allows for a global overview of the evolution, hitherto poorly known, of the French urban system. Only a few partial analyses are available, concerning various periods of time and relative either to urban growth (Gérard, 1974; Goze \& Leymarie, 1978), migrations (Balley, Pumain \& Robic, 1974), the diffusion of economic activities (Noël, Pottier, 1973), or to the evolution of socio-professional structures (APUR, undated). On the other hand, the present approach helps one to assess development planning activities; the policies of spatial rebalancing in the 1960 s essentially concerned towns (métropoles d'équilibre - "counterweight cities" first, 
medium-sized cities later), but have never been assessed comprehensively; besides these policies were based on awareness of territorial disparities and the idea of the spatial interdependence of development. Last, some frequently expressed concerns may be summed up in a simple question: "Do towns tend to look increasingly alike?" This issue is linked to the factors of stability, increase, reduction or modification of the bases for the structural diversification of the urban system. Such diversification is often assessed according to factors of functional specialisation, infrastructural inequalities, disparities in social structures and revenues; it is also assessed by means of the various levels of participation in economic and demographic growth through perception of urban standards of living. Determining the permanent or transitory nature, and therefore the degree of necessity, of such diversification is indeed a systemic issue (Bourne, 1975).

Given the current state of our knowledge, the assertion that a nationwide urban entity is a system should be envisaged as a working hypothesis. Indeed it is difficult to test the idea satisfactorily, since the movements between agglomerations are most of ten inadequately accounted for, with the exception of population migrations. It is therefore in a restrictive sense - compared to that used in system analysis - that we use the notion of urban system for the time being. It is hereby defined as a set of towns that interact on a functional basis. Functional relations bring some permanence to the structure of the system and affect its evolution. We give a partial picture of the system's structure not only on account of the necessarily limited number of variables retained (table I) but also by reason of the nature of the linkages evidenced. Indeed, only relations of spatial co-occurrence or temporal co-variation have been used to define structural status at a given time on the one hand, and the evolution of the system on the other. The reciprocal influences of variables (feedback effects in particular) could not be assessed.

The system's structure is delineated from a number of independent dimensions which characterise the status of the system at a given point in time. Each of these dimensions, or components, constitutes a set of correlated variables (either geographically associated or exclusive) that classify urban areas independently of the other urban characteristics. Thus the structure of the urban system is outlined in the same way as intra-urban organisation through factorial ecology. Although the picture is partial and static, it nevertheless reveals some operational aspects of the structure. Similarly, the comparison of the form of this structure at various points in time reveals the nature of some evolutionary processes within the system (table I).

\section{TABLE I}

Methodology and sources

The main procedures followed to measure structural change:

- Principal components analysis of a matrix including basic tables (urban areas X variables) at various dates. This "analysis of states" describes urban area progress in time within the system's structure. Global change is measured here.

- Principal components analysis of the residuals from the regression, for each variable, from last to initial period of time; analysis of ternary data (Vielajus, 1976); using these two methods, one can eliminate the change common to all urban areas and measure the differential changes that modify the relative positions of towns within the urban system.

Urban areas and variables under consideration. According to the analysis being performed, the following sources were used: 138 urban areas with over 20,000 inhabitants in 1954; 88 urban areas with more than 50,000 inhabitants in 1968; or 99 urban areas with no fewer than 50,000 inhabitants as of 1975 .

Variable types and number of urban areas

\begin{tabular}{|c|c|c|c|c|c|}
\hline \multicolumn{2}{|c|}{ Variable types } & 1954 & 1962 & 1968 & 1975 \\
\hline \multirow{2}{*}{$\begin{array}{l}\text { Working population } \\
\text { in } 20 \text { classes } \\
\text { of economic activity }\end{array}$} & \begin{tabular}{|l} 
place \\
of residence
\end{tabular} & 138 & - & - & 99 \\
\hline & place of work & - & 138 & 138 & - \\
\hline \multirow{2}{*}{$\begin{array}{l}\text { Working population } \\
\text { in } 25 \text { classes } \\
\text { of economic activity }\end{array}$} & $\begin{array}{l}\text { place } \\
\text { of residence }\end{array}$ & - & - & - & 99 \\
\hline & place of work & - & 138 & 138 & - \\
\hline \multicolumn{2}{|c|}{$\begin{array}{c}\text { Working population } \\
\text { in } 10 \text { socio-professional classes }\end{array}$} & 138 & - & 138 & - \\
\hline \multicolumn{2}{|c|}{$\begin{array}{c}\text { Working population } \\
\text { in } 24 \text { socio-professional classes }\end{array}$} & - & - & 138 & - \\
\hline \multirow{3}{*}{$\begin{array}{l}\text { Wages: } \\
\text { relative } \\
\text { level }\end{array}$} & \begin{tabular}{|l|} 
all classes \\
\end{tabular} & - & $88^{*}$ & $88^{*}$ & - \\
\hline & \begin{tabular}{|l} 
workers \\
\end{tabular} & - & - & $88^{*}$ & - \\
\hline & employees & - & - & $88^{*}$ & - \\
\hline \multicolumn{2}{|c|}{ wealth index } & $88^{*}$ & - & $88^{*}$ & - \\
\hline \multicolumn{2}{|c|}{ rate of growth } & 138 & 138 & 138 & \\
\hline \multicolumn{2}{|c|}{ migration filter } & 88 & 88 & 88 & \\
\hline
\end{tabular}

*Dates do not correspond exactly to census dates: wages, 1963 and 1970; wealth index, 1957 and 1971. 


\section{The general processes of change and the movement of translation of the urban system}

To local observers, the changes taking place within each urban area between 1954 and 1975 may have appeared as a complete upheaval of the area's prior structures, a unique bend in its destiny. Actually most of the observed transformations have simultaneously affected all French towns. They are well known, owing to their magnitude; as they are to be found everywhere however, they have hardly altered the relative positions of towns within the urban system. They have mainly resulted in a translation of the whole system.

\section{Processes of change}

Population growth was very rapid until 1968 (more than 2 per cent per year from 1954 to 1968 for urban areas over 50,000 inhabitants) and slightly slower between 1968 and 1975 (1.3 per cent annually on average), although distributed irregularly (disparities in growth rates even increased between 1954 and 1975). This growth has not appreciably modified the size order of towns, hence the urban hierarchy; the correlation between population distributions at various dates is about 0,98 .

A fairly general transformation of urban activities and society occurred at the same time, whose major dimensions are as follows:

a. A process of tertiarisation affected all urban areas between 1962 and 1968, and again two thirds of these until 1975. Thus the share of urban employment in tertiary activities went from 55 to 59 per cent. On the whole, and with the exception of a few cases between 1954 and 1962 (notably industrialisation and the rapid growth of towns in Lorraine), the growth of urban areas has been all the more rapid as they became tertiary. This observation does not invalidate the hypothesis according to which industrialisation is the engine of urban growth. Indeed, apart from "accidents" (such as the arrival, between 1962 and 1968, of repatriated French citizens in tertiary towns in southem France), the most durable and important increases - associated with positive interurban migratory exchanges and based on the modern developments of economic structures (e.g. high wages) - all took place in urban areas with a major share of growing industries. Some towns in the Rhône-Alpes region (Annecy, Grenoble) are good examples of this.

b. A process of substitution is the second factor behind the evolution of urban socio-economic structures, mostly from 1962 onwards. Owing to its magnitude and pervasiveness, it has even become the primary process of change in the urban system since 1968, more important than tertiarisation. It represents the gradual replacement of declining economic activities and social categories by activities and professions which are on the rise; this in the industrial sector as well as in the tertiary sector. Thus growing sectors (metallurgic work, chemicals, some services) have replaced activities with declining employment (textile and food industries, trades). In parallel, salaried jobs are being substituted for those of independent workers, and the share of secondary jobs requiring little or no skill is growing at the expense of more qualified labour categories. This process therefore has associated urban profiles with the implementation of new technologies that have rapidly diffused throughout French towns. It represents economic restructuring and the speeding up of integration.

The data that we have analysed also disclose other transformations that have affected more or less all urban areas, e.g. the increase in wage levels and purchasing power. Observations regarding other urban characteristics (housing, municipal finances, etc.) would probably lead to the same conclusion: the most important and most visible socio-economic changes that have occurred in French urban areas since World War I have entailed a displacement of the structure of the system as a whole, much more than they have modified its form.

\section{The movement of translation of the urban system}

The structure of the French urban system was indeed rather stable between 1954 and 1975. In particular, the dimension that most differentiates urban areas stayed approximately the same (correlation: $r=0.8$, see fig. 1 ). It ranks towns according to the quality of their "image"; this term designates a basic factor of differentiation among towns, generally linked to their degree of attractiveness within the mental representation of the urban network. It combines 


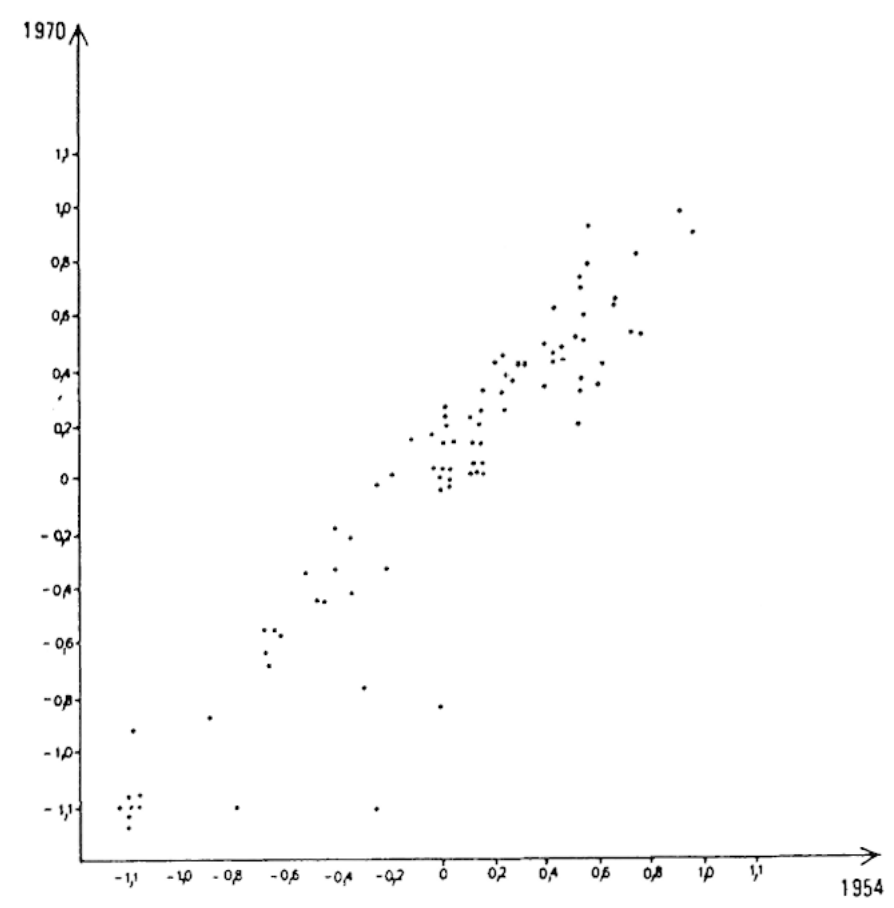

Fig. 1 - Continuity of the structure: positions of urban areas on an "image" axis.

the major orientation of economic activity (production or services), reinforced by the prevailing social features, the level of wealth and the type of demographic evolution. This image dimension thus contrasts urban areas featuring associated tertiary activities and privileged social groups, which are also rich, very attractive and growing fairly strongly (e.g. Cannes, Aix-en-Provence, Nice, Montpellier) with areas of heavy industry characterised by a large bluecollar population, where living standards are low, which stagnate in demographic terms and show negative interurban migratory exchanges (e.g. Lens, Denain, Forbach, Montceau-les-Mines).

Other links shown by secondary dimensions of the urban system have also kept very stable; such is the case of the lack of connection between wage levels in some urban areas and from the image of these areas (the highest average salaries do not appear in towns with the best standards of living). Similarly there is a contrast in the social structures of tertiary urban areas, between profiles associated with independent workers (Perpignan, Bayonne) and those characterised by the number of public employees (Toulouse, Metz).
Compared to the magnitude of the transformations common to all urban units, which account for the persistence of a large number of basic differential features between towns, changes may appear unimportant. They are not limited however to chance modifications in the relative socio-economic situations of towns. Trends towards a reorganisation of the system have emerged with specific combinations of general processes applying to groups of specific urban areas. Therefore as towns evolve at different speeds and some of these differential evolutions depend on initial socio-economic situations, the structure of the system changes little by little. Some of these differential changes simultaneously affect a large number of urban indicators and cluster into two essential movements that are independent from one another. The first affects the towns' image dimension and tends to homogenise urban socioeconomic situations by toning down contrasts in this area. The second, on the contrary, implies a widening of disparities; it gradually leads to reinforcing a new principle of urban differentiation independently of related "images".

\section{The scaling down of "image" disparities}

Although urban areas as a whole have kept the same rank in the major dimension of the organisation of urban socioeconomic structures, although they have therefore kept approximately the same relative positions in relation to their "image", they have nevertheless got closer to each other on that scale. A scaling down of disparities between urban areas has taken place on account of the process of tertiarisation and spatial redistribution of activities. This trend towards homogenisation has appeared through the bringing together of activity structures and socio-professional structures and the attenuation of inequalities between the levels of wages and purchasing power for the urban areas concemed. It is essentially the result of smaller extremes in terms of functional specialisation, be they industrial or tertiary.

\section{Decrease in strong specialisations}

Thus about thirty urban areas whose employment is dominated by one or two sectors of industrial activity have reduced the intensity of their specialisation while recapturing tertiary activities, thereby mitigating their deficiencies in this area. As a consequence the monolithic 
Fig. 2 - The spatial distribution of change in the French urban system 1954-1975.

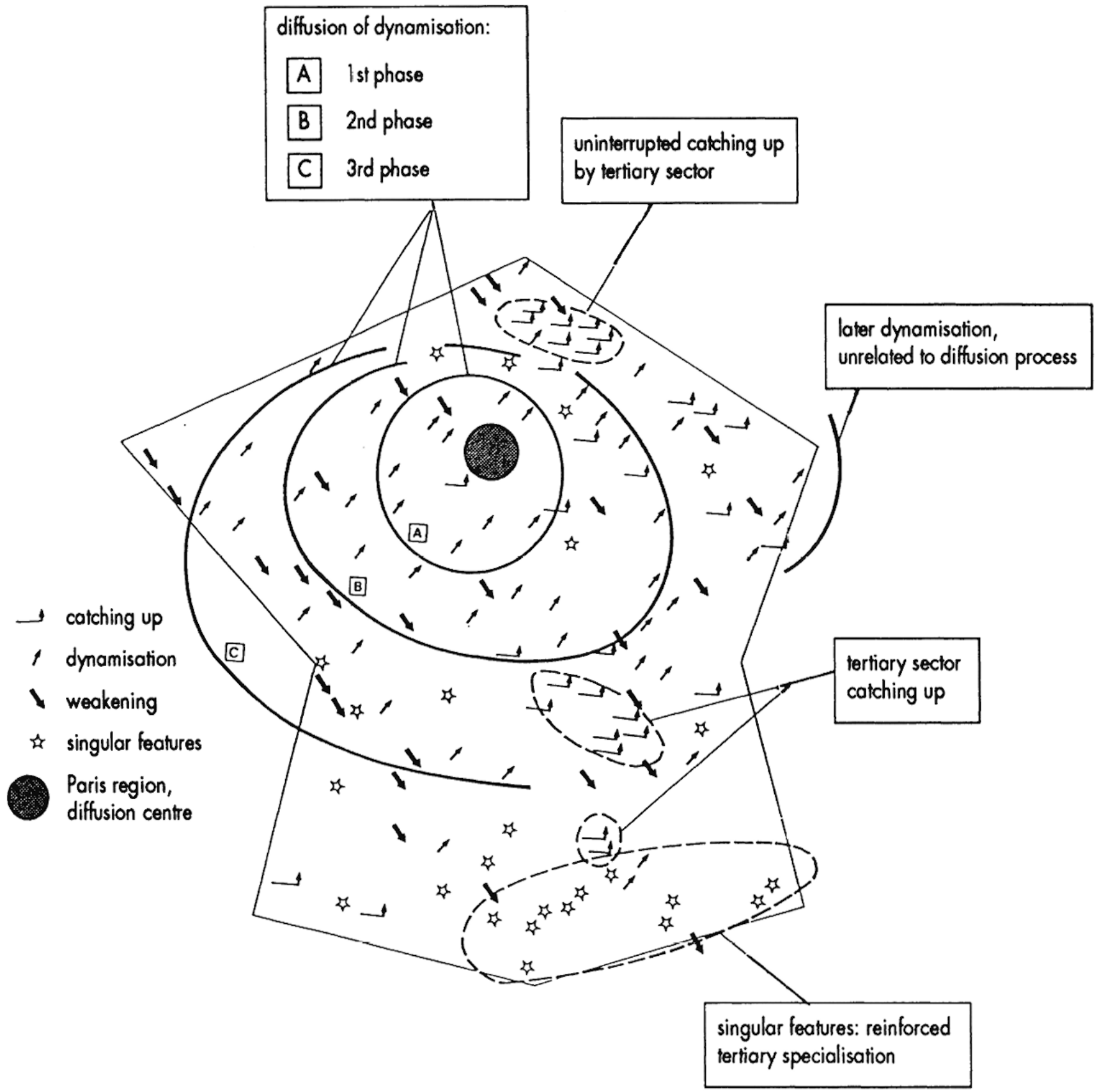

Catching up: Alès, Annecy, Bayonne, Béthune, Bruay-en-Artois, Cambrai, Clermond-Ferrand, Denain, Douai, Epernay, Epinal, Forbach, Lens, Lille, Longwy, La Grand-Combe, Maubeuge, Montceau-les-Mines, Montlufon, Mulhouse, Roanne, Saint-Chamond, Saint-Dizier, Saint-Etienne, Saint-Quentin, Sens, Tarbes,Thionville, Valenciennes, Vienne, Vichy.

Dynamisation: Alençon, Angers, Angoulême, Arles, Arras, Aurillac, Avignon, Beauvais, Belfort, Blois, Bourg-en-Bresse, Bourges, Brive, Caen, Chalon-sur-Saône, Châlons-sur-Marne, Charleville, Chartres, Chateauroux, Chaumont, Cherbourg, Colmar, Compiègne, Creil, Dijon, Dôle, Dunkerque, Elbeuf, Evreux, Grenoble, Laon, Laval, La Roche-surs-Yon, Le Mans, Lorient, Mâcon, Montauban, Moulins, Montargis, Montbéliard, Nevers, Niort, Orléans, Poitiers, Reims, Rennes, Saint-Brieuc, Strasbourg, Tours, Vannes, Verdun.

Weakening: Agen, Amentières, Bergerac, Besançon, Boulogne, Brest, Calais, Castres, Chatellerault, Cholet, Le Creusot, Fougères, Le Havre, Le Puy, Metz, Nantes, Périqueux, Quimper, Rochefort, Romans, Rouen, Saint-Dié, Saintes, Saint-Nazaire, Troyes, Vierzon, Villefranche-sur-Saône.

Singular features: Aix-en-Provence, Albi, Amiens, Auxerre, Béziers, Bordeaux, Cannes, Carcassonne, Chambéry, Cognac, Dieppe, La Rochelle, Limoges, Marseille, Montpellier, Nancy, Narbonne, Nice, Nìmes, Pau, Perpignan, Rodez, Sète, Toulouse, Soissons. 
aspect of social structures in these urban units has lessened in proportion. Most mining or ironworks towns in northern France and the eastern edge of Massif Central belong to this category (fig. 2). Conversely, an industrial recovery has allowed about thirty urban areas, among the most tertiary at the outset, to increase their proportion of secondary jobs (Poitiers, La Roche-sur-Yon). Further, a number of smallscale specialisations have appeared in towns with an average profile (Alençon, Caen, Bourg-en-Bresse, etc.). This industrial recovery has been characterised in particular by an increase in population growth rates. Appearing gradually in increasingly larger halos centered on the Paris region (fig. 2), it is the only transformation of the urban weft to reach such a large number of towns, step by step. It corresponds essentially to a process of geographical diffusion of expanding activities. The process has taken place at nation-wide scale, in connection with the fragmentation of growth in the Paris region, the relative decrease in its concentration, and without any obvious interference from secondary centres of diffusion.

Several factors have contributed to homogenising socioeconomic structures by reducing specialisation where it was most marked. In relation to the change in the relative importance of the various factors of production, some factors have generally favoured greater ubiquity of activities (technological evolution of transportation, cost of labour, of migration...). Other factors are linked to increasingly unfavourable opinions regarding excessive urban specialisations. In this respect, the viewpoints of entrepreneurs, administrations and workers are often convergent, even when their respective underlying reasons are appreciably different.

\section{Homogenisation of profiles}

The increasing degree of ubiquity of most economic activities has not only narrowed the range of situations. It has contributed to mitigating disparities for all urban areas by erasing most of the under-represented phenomena. Thus the minimum base of activity common to all urban areas has increased considerably. As measured by the minimum employment coefficient (Alexandersson, 1956, Moore, 1975), the ubiquitous share of urban jobs (for 20 categories of activity) went from 35 per cent in 1954 to over 45 per cent in 1975, for 95 per cent of urban areas. The same observation applies to most socio-professional categories, whose relative importance within urban areas is more uniformly distributed at the end than at the beginning of the period under consideration.

It would be difficult to attribute this homogenisation of structures solely to the demographic expansion of all urban areas. The link between the degree of specialisation of the activity profile or the degree of particularism in the social structure on the one hand, and the size of urban areas on the other, was already rather loose in 1954 and was even more so at the end of the period. Neither is there a straightforward connection between the process of diversification of activities in a town and the latter's rate of growth over time. Yet a noticeable convergence of socio-economic structures in métropoles d'équilibre ("counterweight cities") has occurred, towards what one may call a "large city" model. They all exhibit activity profiles that are close to the average profile for all towns, with a predominating tertiary sector and with functions of production and transit that take precedence over their central place activities. Although their social structures are not (with the exception of Lille) really blue-collar structures, yet they cannot be defined as "bourgeois" towns; they are better characterised by the predominance of employees in the tertiary sector. As far as incomes and salaries are concerned, their standards of living are not very high but they are always clearly above average. It is difficult to determine what derives strictly from their role as métropoles d'équilibre and from the programmes of infrastructure and activity development that have benefited such urban areas. Indeed, many towns of equal size in other industrialised countries show similar features (see Borchert, 1972), which some authors have interpreted in the light of the theory of self-induced growth (Thompson, 1972).

\section{New forms of diversification}

The homogenisation of socio-economic structures should be seen as a transitory process of regulation within a given period. Indeed, in the last twenty years, this process has been wide enough to stand as the major orientation of the reorganisation of urban structures in France. But it would be unjustified to interpret it as a now irreversible trend leading towards an increasingly stronger similarity of urban profiles. 


\section{Some overspecialisations}

Indeed, one may first see that, beyond this process, some urban areas have expanded their functional specialisation. This emphasis can be explained in all cases by the exploitation of non-substitutable factors of production spatially concentrated and exhibiting much inertia. The new fact is simply that these overspecialisations are now more frequently linked to the development of tertiary consumption than to general trends in industrial location policies. Overspecialisation is particularly obvious in a large number of towns in south eastem France, in connection with leisure and tourist activities on the coast and surrounding areas. Elsewhere, cases of overspecialisation are scattered. In general they concem small centres that have taken a much lesser part than the system as a whole in the general process of growth and functional restructurings (Tarbes, Auxerre, fig. 2).

\section{The emergence of now forms of urban diversification}

The last twenty years have been primarily marked by the emergence and gradual reinforcement of a new structural dimension in the urban system. This has become evident through new connections between structural attributes which are causing increasing segregation among urban areas. This new dimension combines several items: the weight of the most dynamic sectors within the activity structure, the comparative importance of salaried workers within the activity structure, the level of wages, demographic vitality and the balance of interurban migratory exchanges (fig. 3). Two clusters of towns are located at opposite extremes. The first includes urban areas where the newest forms of industrial development are concentrated, where salaried workers are well represented in the service sector, and where the average wage level is relatively high; these towns have also benefited from a positive balance in inter-city migration (e.g. Lyons, Annecy, Dunkirk). The opposite cluster includes urban areas characterised by ageing activity structures, a relatively important share of independent workers, the predominance of low salaries and very small rates of population growth (Perigueux, Perpignan, Agen, Cherbourg, Toulon).

We interpret the emergence of these new connections as being part of an urban system which is modernising itself, in

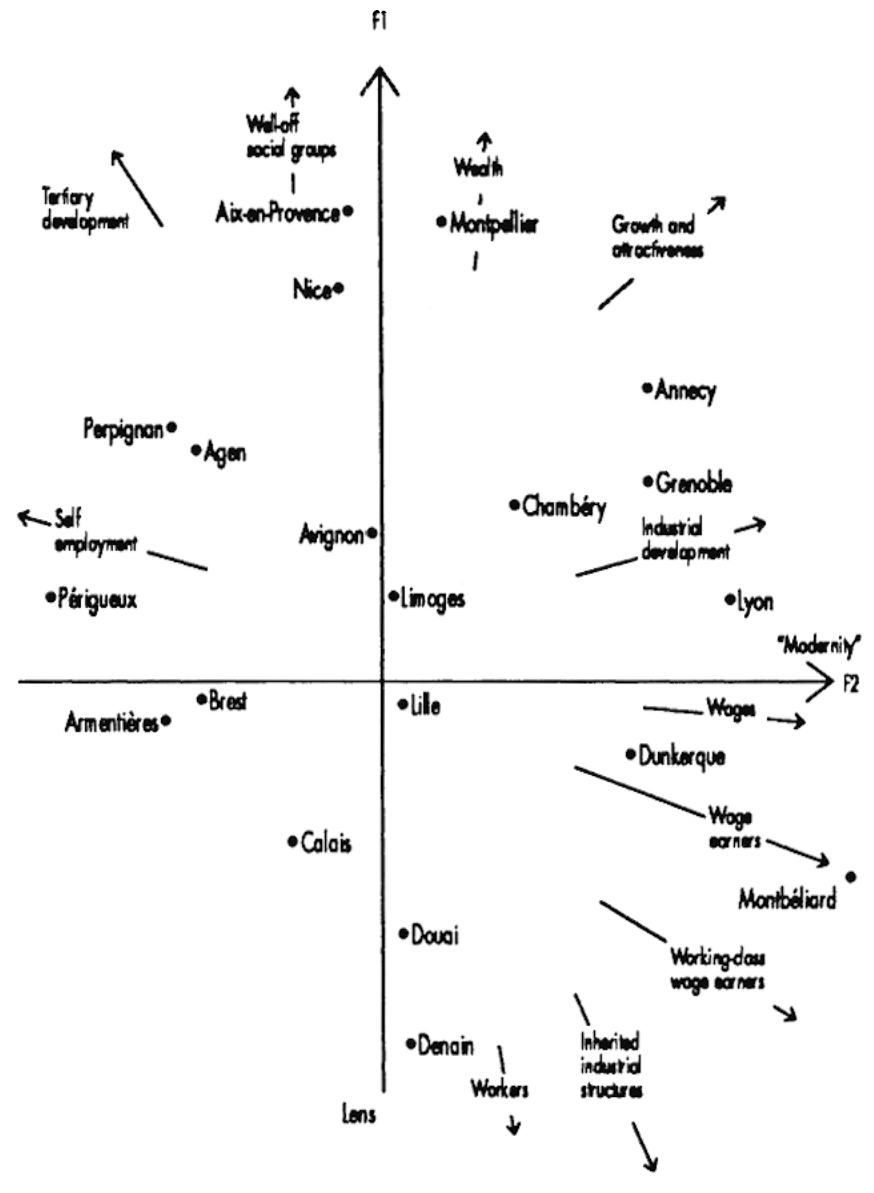

Fig. 3 - The socio-economic situation of cities around (1970).

connection with the unique characteristics of economic growth during that period. They indeed provide a rather accurate image of the uneven diffusion of economic and technological progress among towns. This structural component, begun in 1962 and continuously reinforced until now, tends to re-arrange urban units according to which stage they have reached in the general process of development, and according to their differential capacity to stabilise and diffuse growth. It separates growth centres from the most "peripheral" units in the system.

Using analytical and interpretative approaches that are apparently very different, theories of "polarised development", "unequal exchange" and "innovation diffusion" all agree that the permanence of development partly rests on the continuous creation of disparities. Urban segregations that have appeared during the period under 
consideration are relevant in this context: they bear the mark of current conditions of development.

\section{a. Segregation and hierarchical organisation}

As one finds a sign of the specific forms of the diffusion of recent growth in the new disparities which are emerging between provincial towns, one may rightly wonder about the way this diffusion has taken place in relation to urban hierarchy, beyond the well-known dichotomy that isolates the urban area of Paris from the other urban areas in France. Indeed, some hypotheses attribute a key role as a relay-station to larger towns, owing to the agglomeration economies that they can generate. In their turn, these large urban areas may, more or less gradually, tend to impose on more "peripheral" centres the model of growth that ensured their own development. In this respect, the "peripheral" position of a centre is defined less in terms of distance than in terms of the nature, quality and intensity of interrelationships, i.e. "qualitative" attributes that do not seem quite independent from the size of urban units.

In reality, there is no correlation between the position of urban areas in relation to this new component and their size. Some relevant although less complete regularities may however be observed. Three-fourths of the urban areas over 180,000 inhabitants as of 1975 are "growth centres". All métropoles d" équilibre fall into that category. The other capitals of official regions show more contrasting positions, but their differential, particularly rapid, evolutions tend to bring them much closer to ther most dynamic centres. "Peripheral" new centres make up a more heterogeneous group, with a very large number of small towns, and also urban areas whose "peripheral" situation is defined less by their size than by important structural barriers. Although, on the whole, large towns have often been key centres as far as the diffusion of recent economic growth is concerned, one cannot conclude, at least over this short period, that this process has systematically gone through the various steps of the traditional urban hierarchy.

\section{b. Segregation and social specialisation}

Mostly in reference to the theory of unequal exchange, and transferring intemational space to the national context, $\mathrm{Ph}$. Aydalot (1976) has analysed a specific aspect of this segregative process. He believes that, under the effect of the acceleration of the spatial division of labour, a new hierarchy of urban centres is being born. It rests on social specialisation of the population, specialisation defined in accordance with the level of labour qualification and compensation. In the last few years, major cities have gradually lost a large share of activities that now depend on mass-production procedures. According to Aydalot again, such activities have been displaced towards centres whose "peripheral location" is primarily defined in terms of the small level of labour compensation. This pattern has frequently proved relevant for the two entities of Paris and the provinces. It does not seem to apply to the rest of the network; we have observed that after these twenty years, the appearance of a new source of diversification of urban structures does not yet mean a clear differentiation of social structures that would rest on the level of qualification for the totality of wage labour. At the most, one may note that the relative variations in the share of unskilled blue-collar jobs within urban units have followed the following hypothesis: relatively overskilled jobs in "growth centres", underskilled jobs in "peripheral centres". This slow process of relative redistribution has not upset the existing social equilibria. Furthermore, substitutions and equalisations may have taken place between tertiary and industrial jobs, since the tertiarisation of the largest centres is mostly expressed by rapid growth in the number of jobs demanding lesser skills.

\section{Conclusion}

As a result of our survey, one can interpret the changes in the nature and distribution of inequalities within the urban system over the last twenty years as being two opposite motions that have affected the degree of system diversification. One diminished a source variability based on a functional differentiation of urban areas, this differentiation being itself linked to the unequal spatial concentrations of sectors of activity. The other movement initiated a new source of variability, based less on the nature of the production or service than on the mastery of information and the ability to innovate. This dual movement is only revealed, however, through a large-scale analysis of changes in the relative positions of urban areas within the system, i.e. what we call differential changes. Indeed, the share of "apparent" changes that have simultaneously influenced all urban areas, and have 
therefore entailed a mere transfer of the system, has been essential in the context of the recent transformations of the French urban system.

As one analyses the evolution of urban areas as a whole, one realises the pervasiveness of the transformations experienced by French towns in the last twenty years; local perceptions of seemingly exceptional changes at local level should therefore be put into perspective. Actually, most of these transformations have not appreciably modified the structure of the urban system and only express the system's tendency to perpetuate itself.

The really fundamental changes are much less dramatic. Will a recent development - namely, segregation based on the modernity of socio-economic structures - establish itself at this scale as the major factor of urban differentiation? To what extent will this evolution depend on the environment of the urban system?

In this context, one wishes for more comparative studies of changes affecting urban systems. They would help strengthen theoretical bases and improve planning efficiency.

L'Espace géographique, $n^{\circ} 3,1979$.

\section{Roferences}

AleXANDERsson G. (1958). The industrial structure of American cities. Lincoln: University of Nebraska Press, $153 \mathrm{p}$.

APUR $(1954,1962,1968)$. Evolution des structures sociales urbaines en France. No place or date of publication.
AYDALOT Ph. (1976). Dynamique spatiale et developpement inégal. Paris: Economica, 336 p.

Bauley Ch., Pumann D., Robic M.-C. Villes et migrations, t. 2: la fonction de filtre des agglomérations françaises de plus de 50000 habitants. INED, Contrat de recherche $n^{\circ} 7204$.

BERRY B.J.L. (1964). "Cities as systems within systems of cities." Papers and proceedings of the Regional Science Association, $\mathrm{n}^{\circ} 13, \mathrm{p} .147-163$.

BORCHERT J.R. (1972). “America's changing metropolitan regions". Annals of the Association of American Geographers, $n^{\circ} 62$, p. 352-373.

BOURNE L.S. (1975). Urban systems, strategies for regulation. A comparison of policies in Britain, Sweden, Australia and Carada. Oxford: Clarendon Press, 264 p.

Gerard M.C. (1974). "Aspects démographiques de l'urbanisation, Analyse 1968". Les Collections de l'INSEE, série $\mathrm{D}, \mathrm{n}^{\circ} 30,140 \mathrm{p}$.

Goze M. \& Leymarie D. (1978). "Croissance des agglomérations et villes-centres". Revue économique du SudOuest, $n^{\circ} 2$, p. 123-171.

MOORE C.L. (1975). "A new look at the minimum requirement approach to regional economic analysis". Economic Geography, vol. $51, n^{\circ} 4$.

NOEL M. \& POTtIER CI. (1973). Evolution de la structure des emplois dans les villes françaises. Paris: éditions Cujas (coll. TEM-Espace), $122 \mathrm{p}$.

Pumain D. \& Saint-Julien Th. (1976). "Fonctions et hiérarchies des villes françaises. Etude du contenu des classifications réalisées entre 1960 et 1974". Annales de Géographie, $n^{\circ} 470$, p. 385-440.

Puman D. \& SAITT-Julien Th. (1978). Les dimensions du changement urbain. Evolution des structures socio-économiques du système urbain français de 1954 à 1975 (région parisienne exclue). Paris: CNRS, coll. Mémoires et Documents de Geographie, 202 p.

THOMPSON W.R. (1972). "The national system of cities as an object of public policy". Urban Studies, $n^{\circ}$ 9, p. 99-116.

VieLarus J.L. (1976). Une méthode d' analyse des données termaires: projection simultanée de plusieurs nuages. Xeroxed copy. 